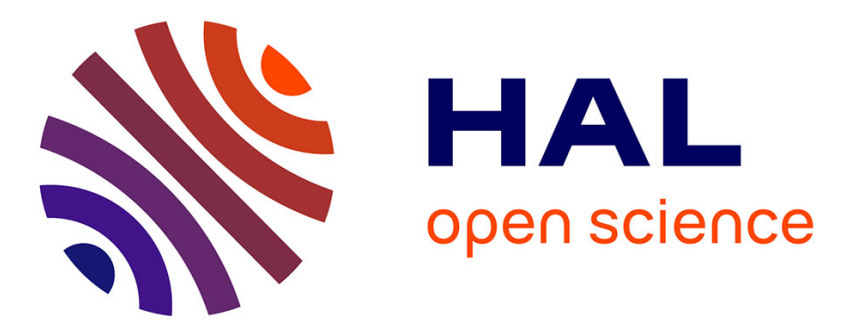

\title{
Comparison Between Finite-Element Analysis and Winding Function Theory for Inductances and Torque Calculation of a Synchronous Reluctance Machine
} Thierry Lubin, Tahar Hamiti, Hubert Razik, Abderrezak Rezzoug

\section{- To cite this version:}

Thierry Lubin, Tahar Hamiti, Hubert Razik, Abderrezak Rezzoug. Comparison Between FiniteElement Analysis and Winding Function Theory for Inductances and Torque Calculation of a Synchronous Reluctance Machine. IEEE Transactions on Magnetics, 2007, 43 (8), pp.3406-3410. 10.1109/TMAG.2007.900404 . hal-00556411

\section{HAL Id: hal-00556411 https://hal.science/hal-00556411}

Submitted on 4 May 2015

HAL is a multi-disciplinary open access archive for the deposit and dissemination of scientific research documents, whether they are published or not. The documents may come from teaching and research institutions in France or abroad, or from public or private research centers.
L'archive ouverte pluridisciplinaire HAL, est destinée au dépôt et à la diffusion de documents scientifiques de niveau recherche, publiés ou non, émanant des établissements d'enseignement et de recherche français ou étrangers, des laboratoires publics ou privés. 


\title{
Comparison between Finite Element Analysis and Winding Function Theory for Inductances and Torque Calculation of a SynRM
}

\author{
T. Lubin, T. Hamiti, H. Razik, Senior Member, IEEE and A. Rezzoug,
}

\begin{abstract}
This paper compares the prediction of two independent methods for calculating electromagnetic torque and inductances of a Synchronous Reluctance Machine under linear condition. One method is based on Winding Function Analysis (WFA) and the other on Finite Element Analysis (FEA). The rotor geometry, the stator slot effects and the stator winding connections are taking into account. The simulation results obtained by the WFA are compared with the ones obtained by two-dimensional FEA. It is shown that the two methods give approximately the same results but require different computation time.
\end{abstract}

Index Terms - Inductance coefficients, electromagnetic torque, winding function, finite element analysis.

\section{INTRODUCTION}

$\Lambda \mathrm{N}$ accurate self- and mutual inductances calculation is $\mathrm{I}_{\text {necessary to improve the accuracy of the analysis of the }}$ Synchronous Reluctance Motor (SynRM). Because of rotor saliency and stator windings distribution, the self- and mutual inductances of a SynRM are not sinusoidal [1]. The electromagnetic torque produced by this machine presents a pulsating component in addition to the dc component when it's fed by sinusoidal currents [2]. The rotor position dependence of electromagnetic torque and machine inductances can be evaluated by a variety of methods including analytical method, finite element analysis [3]-[4] or winding function theory [5][6]. Finite element method gives accurate results. However, this method is time consuming especially for the simulation of a controlled machine fed by a PWM inverter. In winding function approach, the inductances of the machine are calculated by an integral expression representing the placement of winding turns along the air-gap periphery [5].

This paper compares finite element method and winding function method in terms of precision and computation time for electromagnetic torque and inductances calculation for a SynRM.

Manuscript received February 7, 2006.

Authors are with the Groupe de Recherche en Electrotechnique et Electronique de Nancy, GREEN-CNRS UMR - 7037, Université Henri Poincaré, BP 239, 54506 Vandoeuvre-lès-Nancy Cedex, France (phone : 333 83684127 ; e-mail: thierry.lubin@green.uhp-nancy.fr).

\section{WINDING FUNCTION ANALYSIS}

\section{A. Description of the machine}

The cross-section of the stator and the rotor structure of the studied SynRM is shown in Fig.1. The rotor presents a simple and robust structure without damper bars. The stator is the same as an induction motor and has single layer, concentric-3 phases distributed winding with 36 slots. The machine dimensions details are given in Table I.

It is assumed in winding function analysis that the iron of the rotor and stator has infinite permeability and magnetic saturation is not considered.

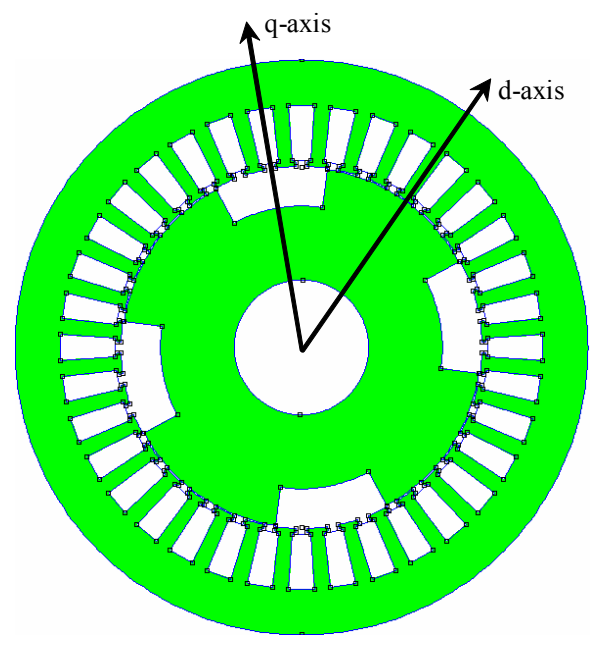

Fig. 1. Cross-section of the studied SynRM.

TABLE I

DIMENSIONS OF THE MACHINE

\begin{tabular}{llc}
\hline \hline Symbol & \multicolumn{1}{c}{ Quantity } & Value \\
\hline $\mathrm{D}$ & Stator outer diameter & $130 \mathrm{~mm}$ \\
$\mathrm{R}$ & Stator inner radius & $40.3 \mathrm{~mm}$ \\
$\mathrm{~L}$ & Active axial length & $75 \mathrm{~mm}$ \\
$\mathrm{n}$ & Number of stator slots & 36 \\
$\mathrm{e}$ & Air gap length & $0.3 \mathrm{~mm}$ \\
$\mathrm{r}$ & Rotor outer radius & $40 \mathrm{~mm}$ \\
$\beta$ & Pole arc/pole pitch & 0.57 \\
$\mathrm{p}$ & Number of poles pairs & 2 \\
& Winding connection & $\mathrm{Y}$ \\
$\mathrm{N}$ & Number of turns & $58 /$ slot \\
$\tau$ & Stator slot pitch & 10 degrees \\
\hline \hline
\end{tabular}




\section{B. Flux density in the air gap}

The flux density in the air gap due to the current flowing in phase "a" is defined to be product of the winding function $\mathrm{Na}(\alpha)$ and the inverse air gap function $\mathrm{e}^{-1}(\alpha-\theta)[7]$ :

$$
\mathrm{B}_{\mathrm{a}}(\theta)=\mu_{0} \mathrm{e}^{-1}(\alpha-\theta) \mathrm{N}_{\mathrm{a}}(\alpha) \text { ia }
$$

where $\theta$ is the angular position of the rotor with respect to the "a" winding reference, $\alpha$ is a particular position along the stator inner surface and $i a$ is the phase "a" current.

The term $\mathrm{Na}(\alpha)$ represents in effect the magnetomotive force distribution along the air-gap for a unit current flowing the winding. The winding function of the phase "a" for the studied SynRM is shown in Fig. 2. The winding function of the phase "b" and phase "c" are similar to that of phase "a" but are displaced by $120^{\circ}$ and $240^{\circ}$ (electrical degrees) respectively.

The inverse air-gap function $\mathrm{e}^{-1}(\alpha-\theta)$ is computed by modeling the flux paths through the air-gap regions using straight lines and circular arc segments [7]. The flux paths due to the rotor saliency are shown in Fig. 3 and the corresponding length of the flux lines is given by:

$\mathrm{E}_{\mathrm{r}}(\alpha-\theta)=\frac{\mathrm{R}\left(\frac{\pi}{2}-|\alpha-\theta|\right)\left(\sin |\alpha-\theta|-\sin \left(\frac{\beta}{2}\right)\right)}{\cos (\alpha-\theta)}$

The flux paths due to the stator slots are shown in Fig. 4 and the corresponding length of the flux lines is given by:

$E_{s}(\alpha)=\left\{\begin{array}{lcl}e+\frac{\pi}{2} R \alpha & \text { for } & 0 \leq R \alpha \leq h_{0} \\ e+\frac{\pi}{2} R \alpha+\gamma(R \alpha-h 0) & \text { for } h_{0} \leq R \alpha \leq \tau / 2\end{array}\right.$

with $\gamma=\frac{\pi}{2}-\arctan \left(\frac{\mathrm{h}_{1}}{\frac{\left(\mathrm{b}_{1}-\mathrm{b}_{0}\right)}{2}}\right)$

where the slot dimensions are $\mathrm{h} 0=0.9 \mathrm{~mm}, \mathrm{~h} 1=0.4 \mathrm{~mm}, \mathrm{~b} 0=$ $2.5 \mathrm{~mm}$ and $\mathrm{b}_{1}=4.3 \mathrm{~mm}$. The total slot depth is $13.6 \mathrm{~mm}$ and the value of the slot opening is $\tau=2.5 \mathrm{~mm}$.

The inverse air-gap function of the SynRM is computed by (4)

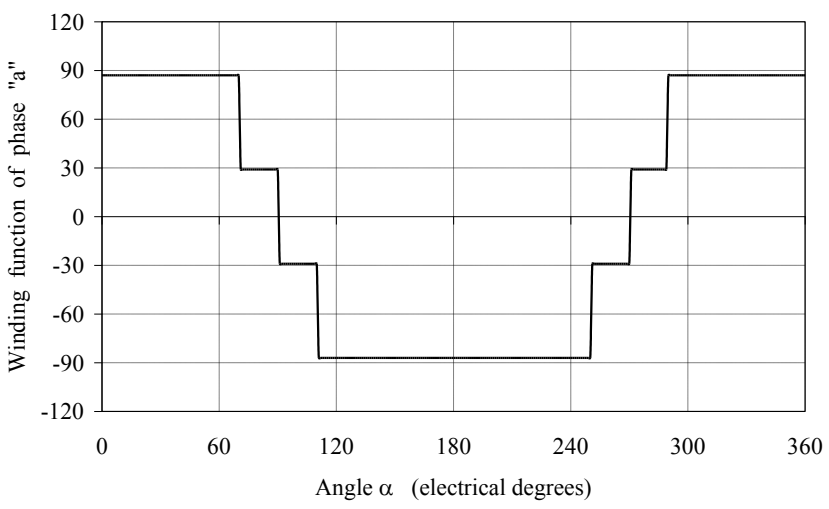

Fig. 2. Winding function of phase "a". and is shown in. Fig. 5 (for $\theta=0^{\circ}$ ).

$\mathrm{e}^{-1}(\alpha-\theta)=\frac{1}{\mathrm{E}_{\mathrm{s}}(\alpha)+\mathrm{E}_{\mathrm{r}}(\alpha-\theta)}$

Based on the previous equations, the air gap flux density distributions of radial direction obtained respectively with dand q-axis excitation are shown in Fig. 6 and Fig. 7. The flux density waveforms present higher harmonics caused by stator slots opening.

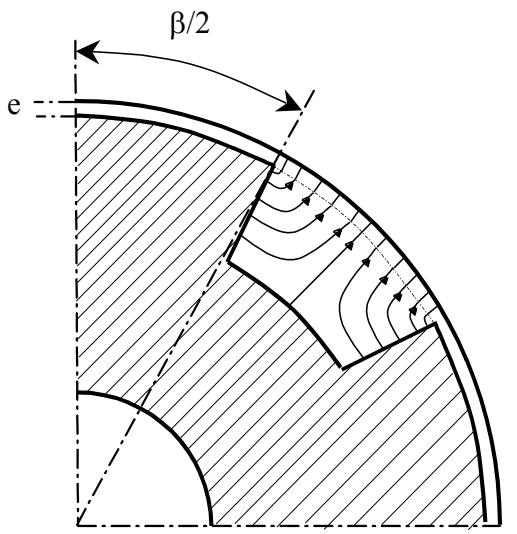

Fig. 3. Flux lines distribution due to the rotor saliency.

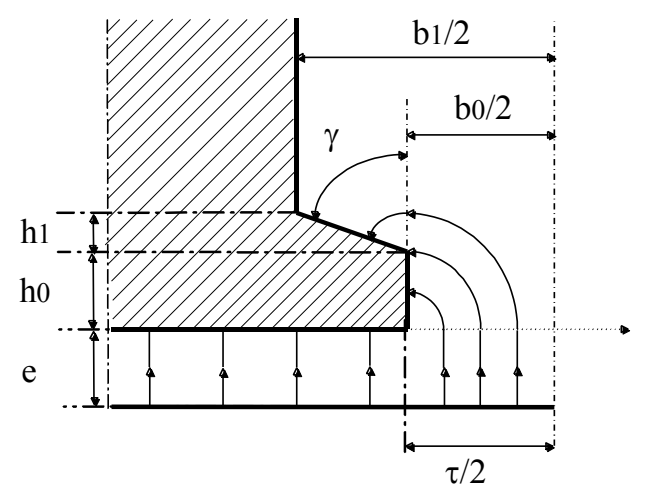

Fig. 4. Flux lines distribution due to the stator slot.

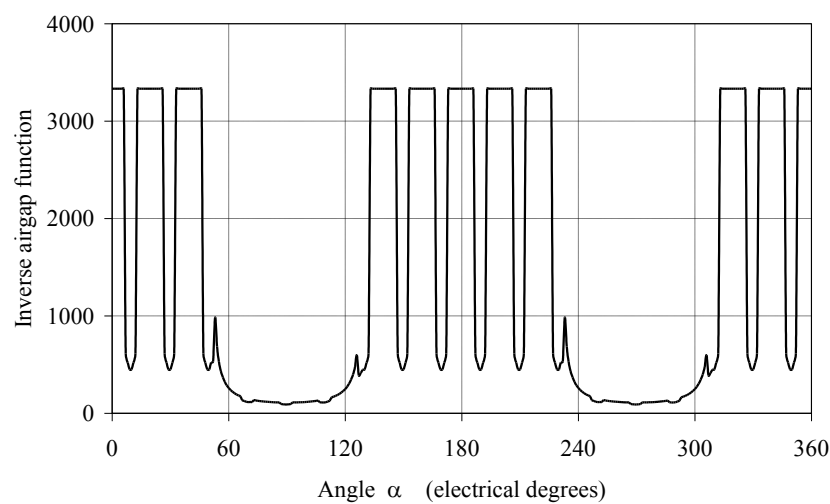

Fig. 5. Inverse air gap function including rotor saliency and stator slots effect. 


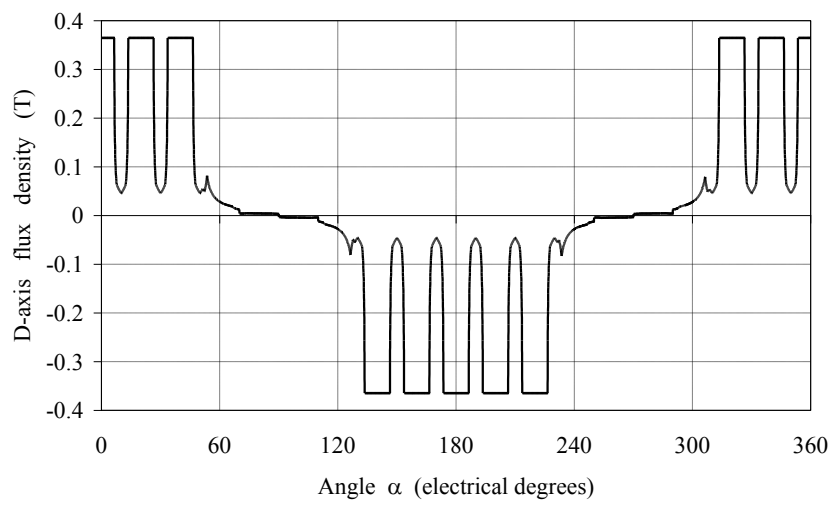

Fig. 6. Air gap radial flux density in $\mathrm{d}$-axis with $\mathrm{ia}=1 \mathrm{~A}$ and $\mathrm{ib}=\mathrm{ic}=0 \mathrm{~A}$.

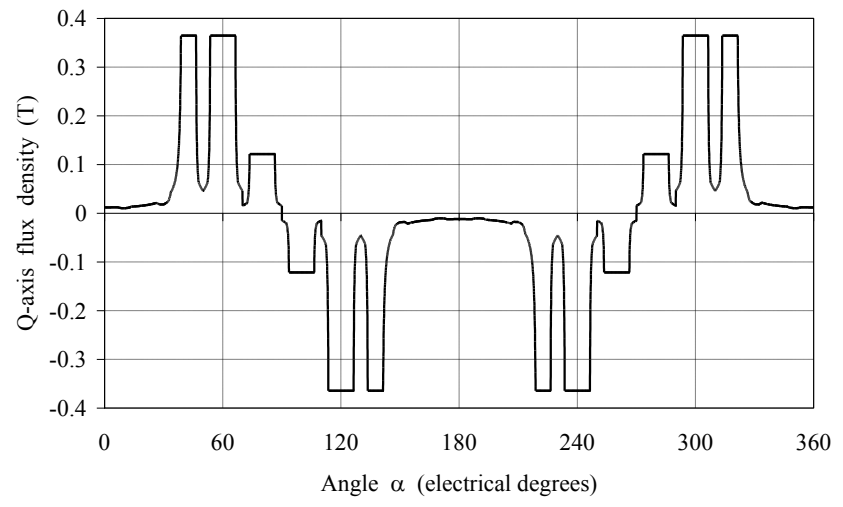

Fig. 7. Air gap radial flux density in $\mathrm{q}$-axis with $\mathrm{ia}=1 \mathrm{~A}$ and $\mathrm{ib}=\mathrm{ic}=0 \mathrm{~A}$

\section{Calculation of stator inductances}

According to the winding function theory, the general expression for mutual inductance between two windings "a" and " $b$ " is given by the following expression [5]:

$$
\operatorname{Lab}(\theta)=\mu_{0} \operatorname{LR} \int_{0}^{2 \pi} \mathrm{e}^{-1}(\alpha-\theta) \mathrm{N}_{\mathrm{a}}(\alpha) \mathrm{N}_{\mathrm{b}}(\alpha) \mathrm{d} \alpha
$$

The self- and mutual inductances of the studied machine has been computed at different rotor positions and are shown in. Fig. 8. The ripple which is present in the inductance profile clearly exhibits the slot effects.

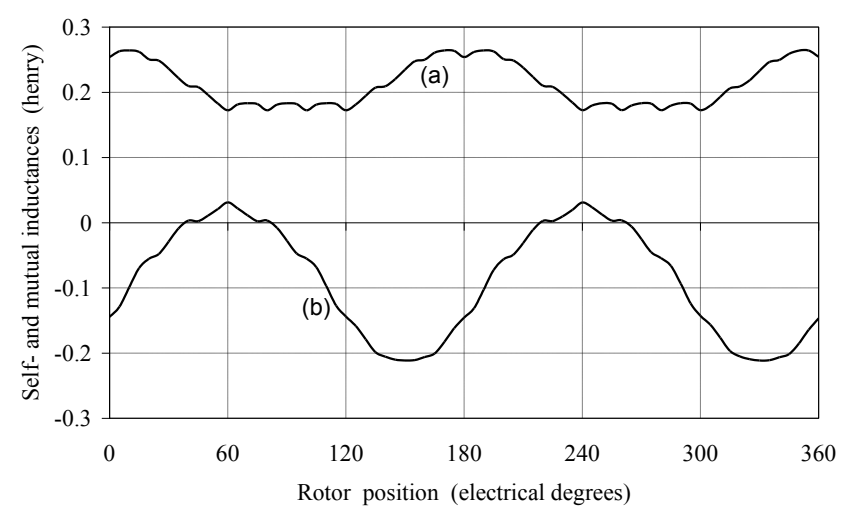

Fig. 8. Winding function analysis: (a) self-inductance profile of stator phase "a"; (b) Mutual inductance profile between stator phase "a" and stator phase "b"

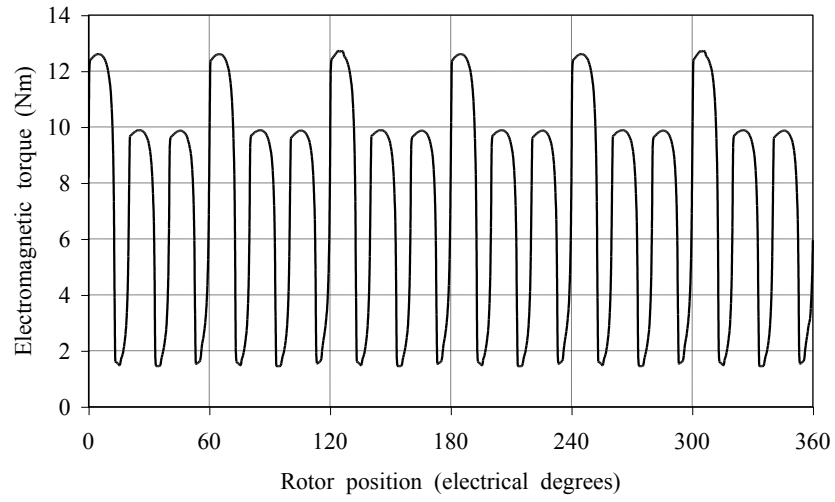

Fig. 9. Calculated torque versus rotor position $\left(\delta=45^{\circ}\right.$; Irms $\left.=3 \mathrm{~A}\right)$; Winding function method

\section{Calculation of the electromagnetic torque}

The machine electromagnetic torque Tem is obtained from the magnetic co-energy $W_{c o}$ :

$\mathrm{T}_{\mathrm{em}}=\left[\frac{\partial \mathrm{W}_{\mathrm{co}}}{\partial \theta}\right]_{(\text {Isconstant })}$

In a linear magnetic system, the co-energy is equal to the stored energy:

$\mathrm{Wco}_{\mathrm{co}}=\frac{1}{2}\left[\mathrm{i}_{\mathrm{s}}\right]^{\mathrm{t}}[\mathrm{L}(\theta)]\left[\mathrm{i}_{\mathrm{s}}\right]$

Therefore, the electromagnetic torque is:

$\mathrm{T}_{\mathrm{em}}=\frac{1}{2}\left[\mathrm{i}_{\mathrm{s}}\right]^{\mathrm{t}}\left[\frac{\partial[\mathrm{L}(\theta)]}{\partial \theta}\right]\left[\mathrm{i}_{\mathrm{s}}\right]$

where $[\mathrm{L}(\theta)]$ is the inductance matrix. The precise knowledge of the inductance matrix is essential for the computation of the electromagnetic torque.

In order to achieve maximum torque per rms current, the stator windings are fed with sinusoidal currents $(\operatorname{Irms}=3 \mathrm{~A})$ with an electrical current phase $\delta$ of $45^{\circ}$. The electromagnetic torque has been computed at different rotor positions and is shown in. Fig. 9. As it appears in Fig. 9, the torque characteristic contains an important pulsating torque component mainly due to stator slots opening.

\section{COMPARISON WITH FinITE ElEMENT ANALYSIS}

\section{A. Air gap flux density distribution}

A 2-D finite element analysis of the SynRM has been performed using the parameters identical to that of the winding function analysis. Highly permeable linear materials were used in the structure in order to match the winding function model which considers infinite permeability. The free software FEMM was used in the simulations [8]. 


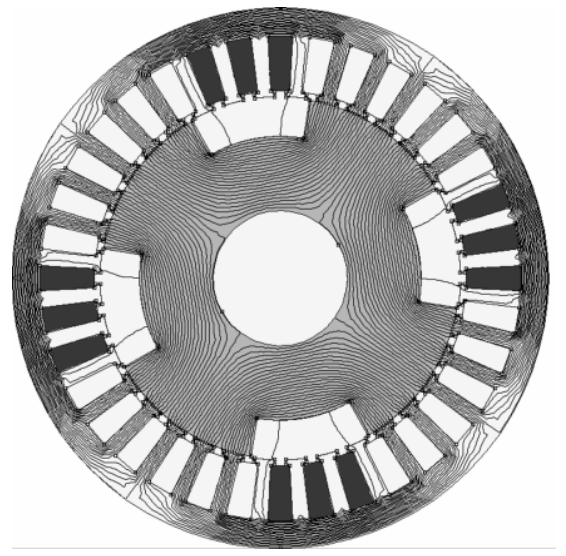

Fig. 10. Flux distribution in d-axis.

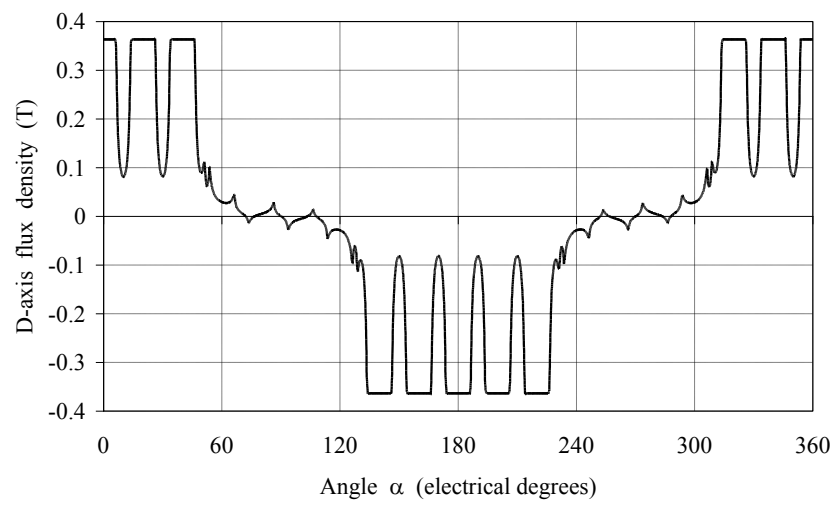

Fig. 11. Airgap radial flux density in $\mathrm{d}$-axis with $\mathrm{ia}=1 \mathrm{~A}$ and $\mathrm{ib}=\mathrm{ic}=0 \mathrm{~A}$.

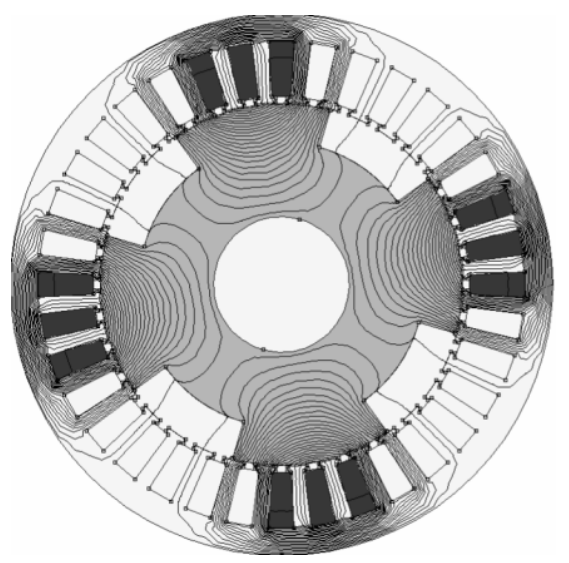

Fig. 12. Flux distribution in q-axis.

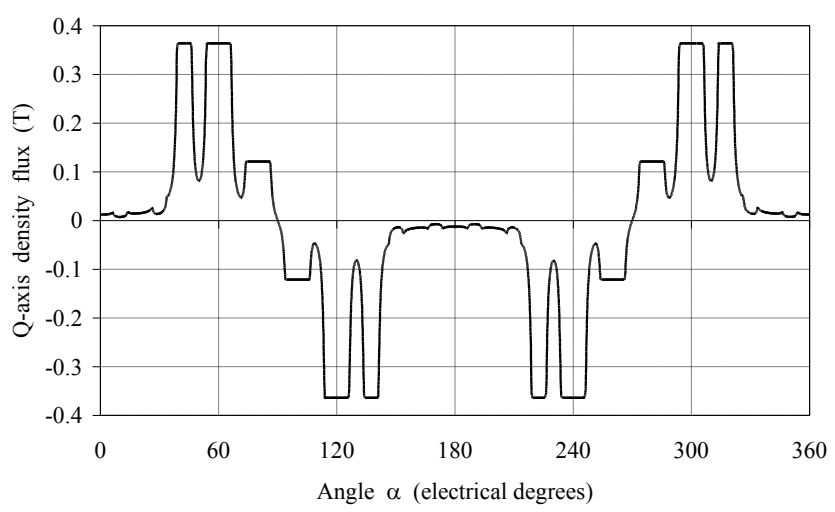

Fig. 13. Airgap radial flux density in $\mathrm{d}$-axis with $\mathrm{ia}=1 \mathrm{~A}$ and $\mathrm{ib}=\mathrm{ic}=0 \mathrm{~A}$.
In Fig. 10 we present the d-axis field distribution obtained with the rotor d-axis aligned with the phase "a" axis and the windings excited according to $\mathrm{ia}=1 \mathrm{~A}$ and $\mathrm{ib}=\mathrm{ic}=0 \mathrm{~A}$. The qaxis field distribution is shown in Fig. 12. The corresponding d- and q-axis air gap radial flux density waveforms are shown in Fig. 11 and Fig. 13. Comparison with Fig. 6 and Fig. 7 indicates a good agreement with the results obtained by the winding function method.

\section{B. Calculation of the stator inductances}

The numerical calculation of the winding "a" self inductance is performed by:

$$
\operatorname{Laa}(\theta)=\iiint_{\mathrm{v}} \mathrm{AJdv} \quad \text { with } \mathrm{i}_{\mathrm{a}}=1 \mathrm{~A} \text { and } \mathrm{i}_{\mathrm{b}}=\mathrm{i}_{\mathrm{c}}=0 \mathrm{~A}
$$

where ia is the current flowing through the winding "a". $\boldsymbol{A}$ and $\boldsymbol{J}$ are the magnetic vector potential and current density.

The mutual inductance between winding " $\mathrm{a}$ " and winding "b" is evaluated by:

$$
\begin{aligned}
& \mathrm{M}_{\mathrm{ab}}(\theta)=\frac{1}{2}\left(\iiint_{\mathrm{v}} \mathrm{AJdv}-\mathrm{L}_{\mathrm{aa}}(\theta)-\mathrm{L}_{\mathrm{bb}}(\theta)\right) \\
& \text { with } \mathrm{i}_{\mathrm{a}}=\mathrm{i}_{\mathrm{b}}=1 \mathrm{~A} \text { and } \mathrm{i}_{\mathrm{c}}=0 \mathrm{~A}
\end{aligned}
$$

The results obtained with the FE method are shown in Fig. 14. These results can be compared with those of Fig. 8 obtained by the winding function method. The significant harmonic terms of the self- and mutual inductances for the two methods are given in Table II and Table III. These comparisons indicate a good agreement between the two methods except on the dc-value of the self inductance. That is due to the stator slots flux leakages which are not taken into account in winding function analysis.

Computation of the self- and mutual inductance profile by finite element analysis at a resolution of $1^{\circ}$ (360 points) takes around 8 hours with a 3-Ghz Pentium IV processor running on Windows XP with 512 MB RAM. Using winding function analysis with $\mathrm{C}$ language programming, the same PC computes all the inductance profiles and the electromagnetic torque with a resolution of $1 / 10^{\circ}$ within 1 minute.

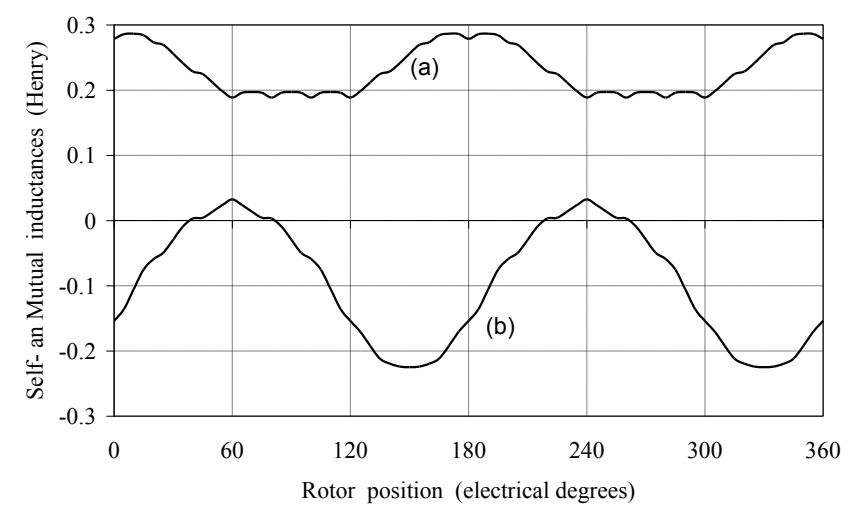

Fig. 14. Finite element analysis: (a) self-inductance profile of stator phase "a"; (b) Mutual inductance profile between stator phase "a" and stator phase 
TABLE II

HARMONICS OF THE SELF-INDUCTANCE (HENRY)

\begin{tabular}{lcc}
\hline \hline $\begin{array}{c}\text { Harmonic } \\
\text { order }\end{array}$ & Winding function method & Finite element method \\
\hline dc-value & 0.213 & 0.232 \\
1 & 0.048 & 0.051 \\
2 & 0.0108 & 0.011 \\
3 & 0.0048 & 0.0045 \\
\hline \hline
\end{tabular}

TABLE III

HARMONICS OF THE MUTUAL INDUCTANCE (HENRY)

\begin{tabular}{lcc}
\hline \hline $\begin{array}{c}\text { Harmonic } \\
\text { order }\end{array}$ & Winding function method & Finite element method \\
\hline dc-value & -0.09 & -0.093 \\
1 & 0.120 & 0.126 \\
2 & 0 & 0 \\
3 & 0.005 & 0.0042 \\
\hline \hline
\end{tabular}

\section{Calculation of the electromagnetic torque}

The electromagnetic torque $T e m$ is calculated by integrating the Maxwell stress tensor along a closed contour of radius $\mathrm{R}$ situated in the air gap. The mesh was constructed to keep the number of nodes as low as possible so as to reduce computational time. However, enough elements were used in the air gap to properly compute the electromagnetic torque by the Maxwell stress tensor [8]. For two-dimensional electromagnetic fields models, the torque is given by:

$\mathrm{T}_{\mathrm{em}}=\frac{\mathrm{R}^{2} \mathrm{~L}}{\mu_{0}} \int_{0}^{2 \pi} \mathrm{B}_{\mathrm{n}}(\theta) \mathrm{B}_{\mathrm{t}}(\theta) \mathrm{d} \theta$

where $\mathrm{Bn}$ and $\mathrm{Bt}$ are the normal and tangential components of the flux density along the contour.

The electromagnetic torque has been computed at different rotor positions and is shown in. Fig. 15. The machine exhibits important torque ripple mainly due to slot effect. The result is close enough to those found by the winding function method (Fig. 9). The torque calculation requires about 4 hours of simulation time (360 points) whereas less than 1 minute is required with the winding function method.

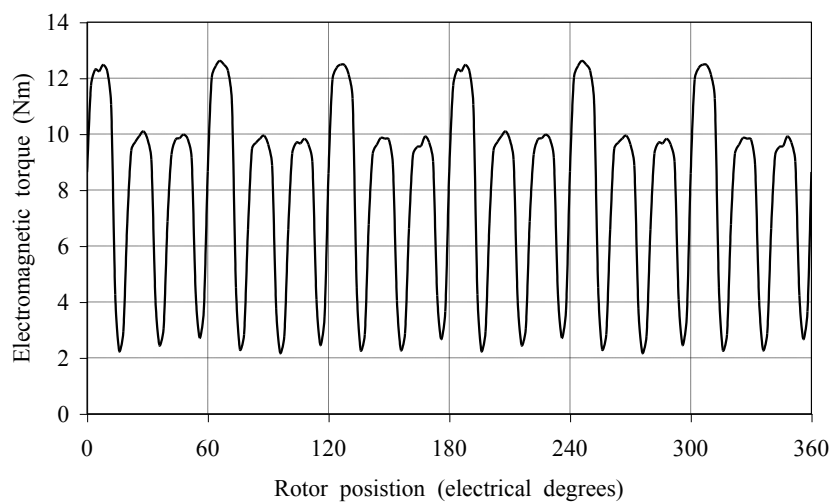

Fig. 15. Calculated torque versus rotor position $\left(\delta=45^{\circ}\right.$, Irms $\left.=3 \mathrm{~A}\right)$; Finite Element method.

\section{CONCLUSION}

Two methods for inductances and electromagnetic torque calculation were compared in terms of precision and computer times. It has been shown that the two methods give similar values of inductances and electromagnetic torque. However, it was clearly shown in this work that the winding function method offers considerable simplicity and lower computational costs. With this approach, parameters sensitivity analysis and the impact on the machine design can be evaluated rapidly (under magnetic linear condition). Winding function method can also be used for motor drive simulations.

\section{REFERENCES}

[1] A. Chiba, F. Nakamura, T. Kukao, and M. A. Rahman, "Inductances of Cageless Reluctance-Synchronous Machines Having Non-sinusoidal Space Distributions", IEEE Trans. Industry Applications, vol. 27, No. 1, pp. 44-51, 1991.

[2] H. A. Toliyat, S. P. Waikar, T. A. Lipo, "Analysis and Simulation of Five-phase Synchronous Reluctance Machine Including Third Harmonic of Airgap MMF", IEEE Trans. Industry Applications, vol. 34, No. 2, pp. 332-339, 1998.

[3] J. H. Lee, "Efficiency evaluation of synchronous reluctance motor using FEM and Preisach modeling," IEEE Trans. Mag., vol. 39, pp. 32713273, Sept. 2003.

[4] A. Vagati, A. Canova, M. Chiampi, M. Pastorelli and M. Repetto, "Design refinement of synchronous reluctance motor through finiteelement analysis", IEEE Trans. Industry Applications, vol. 36, No. 4, pp. 1094-1102, 2000.

[5] I. Tabatabei, J. Faiz, H. Lesani and M. T. Nabavi-Razavi, "Modeling and simulation of a salient-pole synchronous generator with dynamic eccentricity using modified winding function theory," IEEE Trans. Mag., vol. 40, pp. 1550-1555, May 2004

[6] P. Neti, S. Nandi, "Determination of effective air-gap length of reluctance synchronous motors from experimental data", Conf. Rec. IEEE-IAS annual meeting, pp. 86-93, 2004.

[7] P. C. Krause, O. Wasynczuk, and S. D. Sudhoff, Analysis of Electric Machinery. Piscataway, NJ: IEEE Press, 1995.

[8] D. C. Meeker, "Finite Element Method Magnetics", Version 4.0 (17 June 2004 Build), http://femm.foster-miller.net.

\section{BIOGRAPHIES}

Thierry Lubin was born in Sedan, France, in 1970. He received the M. Sc. Degree from the University of Paris 6, France in 1994 and the Ph.D. degree from the University of, Nancy, France, in 2003. He is currently a lecturer with the University of Nancy. His interests include electrical machine, modeling and control.

Tahar Hamiti was born in Tizi-Ouzou, Algeria, in 1979. He received the M. Sc. Degree from the University of Nancy, France in 2003. He is currently working toward the Ph.D degree. His research interests include reluctance machine, modeling and control.

Hubert Razik (M'98, SM'03) received the Ph.D. degree from the Polytechnic Institute of Lorraine in Electrical Engineering, Nancy, France, in 1991. He currently works as a lecturer with the University Henri Poincaré. His fields of research include the modelling, the control and the condition monitoring of multi-phase induction motor.

Abderrezak Rezzoug (M'79) is Professor in Electrical Engineering at the University Henri Poincaré, Nancy, France. He is currently the Dean of the Groupe de Recherche en Electrotechnique et Electronique de Nancy, France. His main subjects of research concern electrical machines, their identification, diagnostics and control, and superconducting applications. 